\title{
Correlation between the hemodynamic gain obtained after operation of primary varicose veins and chronic venous disease classification ${ }^{1}$
}

\author{
Correlação entre o ganho hemodinâmico obtido após a operação de varizes dos membros \\ inferiores e a classificação da doença venosa crônica
}

\begin{abstract}
Nei Rodrigues Alves Dezotti', Edwaldo Edner Joviliano"I, Takachi Moriya ${ }^{\text {II }}$, Carlos Eli Piccinato ${ }^{\text {III }}$
${ }^{I} \mathrm{PhD}$, Division of Vascular and Endovascular Surgery Department of Surgery and Anatomy, FMRP-USP, Ribeirao Preto-SP, Brazil. Main author, responsible for manuscript writing, statistical analysis, critical revision.

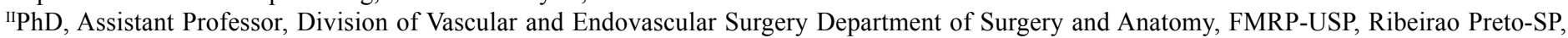
Brazil. Responsible for acquisition and interpretation of data.

${ }^{I I I} \mathrm{PhD}$, Chairman and Head, Division of Vascular and Endovascular Surgery Department of Surgery and Anatomy, FMRP-USP, Ribeirao Preto-SP, Brazil. Responsible for manuscript preparation, statistical analysis, manuscript writing, critical revision.
\end{abstract}

\begin{abstract}
CONTEXT: Previous studies have demonstrated improvement of venous hemodynamics after surgical treatment of primary varicose veins of the lower extremities using air plethysmography (APG).

PURPOSE: To correlate the venous hemodynamics obtained by APG with the CEAP classification after surgical treatment of primary varicose veins.

METHODS: We studied 63 limbs of 39 patients (35 women and 4 men) aged on average 46.3 years, operated upon at the University Hospital, Faculty of Medicine of Ribeirão Preto, University of São Paulo, during the period from January 2001 to December 2004. The 63 limbs were divided into the three following groups according to CEAP classification: group $\mathrm{C}_{2}+\mathrm{C}_{3}(38$ limbs $)$, group $\mathrm{C}_{4}(15$ limbs) and group $\mathrm{C}_{5}+\mathrm{C}_{6}(10 \mathrm{limbs})$. The patients were evaluated clinically before and 30 to 40 days after surgery by preoperative duplex ultrasonography and pre- and postoperative APG.

RESULTS: There was an apparent hemodynamic improvement after surgical treatment of the varicose veins in the two groups of lower severity, but the improvement was significant in the most severe group based on venous filling index.

CONCLUSION: Surgical treatment was beneficial for all three groups, but the greatest hemodynamic gain was observed in the group of highest clinical severity (group $\mathrm{C}_{5}+\mathrm{C}_{6}$ ).

Key words: Varicose Veins. Lower Extremity. Plethysmography.

\section{RESUMO}

CONTEXTO: Estudos prévios tem demonstrado a melhora da hemodinâmica venosa após o tratamento cirúrgico das varizes primárias dos membros inferiores utilizando a pletismografia a ar (PGA).

OBJETIVO: Correlacionar a hemodinâmica venosa obtida pela PGA com a classificação CEAP após tratamento cirúrgico das varizes primárias dos membros inferiores.

MÉTODOS: Foram estudados 63 membros inferiores em 39 pacientes ( 35 mulheres e 4 homens), com idade média igual a 46,3 anos, operados no Hospital das Clínicas da Faculdade de Medicina de Ribeirão Preto da Universidade de São Paulo, no período de janeiro de 2001 a dezembro de 2004. Os 63 membros inferiores foram subdivididos em três grupos de acordo com a classificação CEAP, adotando-se o critério lesão de pele como referência, sendo: grupo $\mathrm{C}_{2}+\mathrm{C}_{3}$ (38 membros) grupo $\mathrm{C}_{4}$ (15 membros) e grupo $\mathrm{C}_{5}+\mathrm{C}_{6}(10$ membros). Os pacientes foram avaliados clinicamente pré e pós-operatório (30 a 40 dias após), mapeamento dúplex pré-operatório e PGA pré e pós-operatória.
\end{abstract}

RESULTADOS: Houve aparente melhora hemodinâmica após tratamento cirúrgico de varizes nos dois grupos de menor gravidade, mas foi significativa no de maior gravidade com base no índice de enchimento venoso.

CONCLUSÃO: O tratamento cirúrgico beneficiou os três grupos, mas o maior ganho hemodinâmico foi observado no grupo de gravidade clínica maior (grupo $\mathrm{C}_{5}+\mathrm{C}_{6}$ ).

Descritores: Varizes. Extremidade Inferior. Pletismografia. 


\section{Introduction}

Primary varicose veins of the lower extremities represent one of the most frequent affections in patients who seek care at vascular surgery outpatient clinics, generating a treatment demand that often exceeds the capacity of the Brazilian public health system ${ }^{1}$.

The clinical manifestations of patients with varicose veins are related to vein valvular incompetence and the consequent venous reflux. Surgical treatment is used to correct the reflux points in order to relieve venous stasis in an attempt to prevent, or at least delay, the progression of venous diseases to more clinically severe stages.

Many authors have used air plethysmography (APG) separately or not for pre- and postoperative evaluation and have made several comparisons, concluding that APG is a good method for the assessment of venous hemodynamics after surgery of primary varicose veins ${ }^{2-10}$. APG, introduced by Christopoulos et $a l .^{2,11}$, measures the various degrees of venous reflux in chronic venous disease by studying the function of the calf muscle pump, the ejection fraction (EF), the residual volume fraction (RVF), as well as the venous filling index. (VFI). It also records the overall parameters of venous function including calf venous volume (VV), important for the understanding of the physiopathology of venous diseases.

The classification of chronic venous diseases (CEAP) has been recently established by a consensus of the medical societies of vascular surgery in order to obtain uniformity in publications on this subject ${ }^{12}$.

In view of the fact that, after operation of varicose veins there is a gain in venous hemodynamics, the objective of the present study was to correlate this hemodynamic gain with the CEAP classification and to assess whether the gain is the same for all levels of clinical severity of this classification.

\section{Methods}

Thirty-nine patients (63 limbs) were evaluated prospectively, 35 of them $(88.6 \%)$ women and $4(1.4 \%)$ of them men, aged on average 46.3 years. The patients were seen at the Outpatient Clinic of the Division of Vascular and Endovascular Surgery, Department of Surgery and Anatomy, Faculty of Medicine of Ribeirão Preto, University of São Paulo (FMRP-USP), and were operated upon by a single surgeon of this Division during the period from January 2001 to December 2004, and selected according to the inclusion and exclusion criteria listed below. The study was approved by the Research Ethics Committee of the University Hospital of Ribeirão Preto, SP, and all subjects gave written informed consent to participate.

Inclusion criteria were: patients with symptomatic varicose veins classified according to the International CEAP classification as follows: Clinical criterion $-\mathrm{C}_{2}$ to $\mathrm{C}_{6}$, Etiological criterion - $\mathrm{E}_{\mathrm{p}}$, Anatomical criterion - $\mathrm{A}_{\mathrm{s}}$, and Physiopathological criterion - $\mathrm{P}_{\mathrm{r}}$ Exclusion criteria were: patients with a history of varicose vein operation, patients with congenital malformations, diabetes mellitus, heart disease, arterial and lymphatic vasculopathies, collagenoses and myopathies, traumatic injuries with or without associated fractures, and isolated or associated arthropathies, and patients who did not give written informed consent.

Thus 63 limbs were included in the study, classified as: $\mathrm{C}_{2}=6(9.5 \%), \mathrm{C}_{3}=32(50.8 \%), \mathrm{C}_{4}=15(23.8 \%), \mathrm{C}_{5}=7(11.1 \%)$ and $\mathrm{C}_{6}=3(4.8 \%)$.

The patients were then reassigned to 3 groups according to the "skin lesion" criterion:

- Group $\mathrm{C}_{2}+\mathrm{C}_{3}$ (38 limbs): no skin lesion (presence of varicose veins without ochre dermitis, dermatofibrosis or dermatosclerosis);

- Group $\mathrm{C}_{4}$ (15 limbs): intermediate skin lesion (ochre dermitis with or withour dermatofibrosis or dermatosclerosis, or both);

- Group $\mathrm{C}_{5}+\mathrm{C}_{6}(10$ limbs): with skin lesion (skin with dermatofibrosis and dermatosclerosis with healed or open phlebopathic ulcers).

The limbs were evaluated by pre- and postoperative clinical examination, preoperative duplex ultrasonography and preand postoperative APG (30 to 40 days after surgery).

\section{Clinical examination}

The patient was examined in the standing position in an illuminated environment, thus permitting the filling and visualization of the superficial varicose veins. The medial, lateral, anterior and posterior surfaces of the lower extremities were evaluated.

The exam was carried out according to classical semiologic standards by inspection, palpation, percussion and auscultation, in addition to the tourniquet test.

\section{Duplex ultrasonography}

Duplex ultrasonography was performed in order to exclude patients with diseases of the deep venous system. Highfrequency linear probes $(7.0$ to $10 \mathrm{MHz})$ were used, capable of producing images in the $\mathrm{B}$ mode, color Doppler and spectral curves from the pulse Doppler. An Aspen-Siemens ${ }^{\circledR}$ instrument (Erlangen, Germany) was used. A vein presenting reflux lasting more than 0.5 seconds was considered to be insufficient.

The exams were performed by a single independent examiner, who communicated the results to the senior investigator.

\section{Air plethysmography}

The exams were carried out simultaneously by two examiners preoperatively and between the 30th and 45th postoperative day in the Laboratory of Noninvasive Vascular Investigation of the Division of Vascular and Endovascular Surgery, FMRP-USP, in the afternoon. The maneuvers were started only after demonstration of the exam to the patient and verification that the patient understood it. 
Function of the calf muscle pump was studied by APG. Using an SDV 3000 Angiotec ${ }^{\circledR}$ instrument (Belo Horizonte, Brasil) with computer- automated calibration. The technique described and standardized by Christopoulos et al. ${ }^{1}$ was used for the study and the following parameters were evaluated: VFI, EF and RVF. Literature values considered to be normal are: VFI < $2, \mathrm{EF}>40 \%$ and $\mathrm{RVF}<35 \%{ }^{13}$.

The difference between the pre- and postoperative values of VFI, RVF and EF were considered to represent the hemodynamic changes of each LL operated upon for varicose veins. These hemodynamic changes were correlated between groups $\mathrm{C}_{2}+\mathrm{C}_{3}, \mathrm{C}_{4}$ and $\mathrm{C}_{5}+\mathrm{C}_{6}$ in order to determine whether the hemodynamic change obtained with surgical treatment was correlated with clinical severity.

\section{Surgical treatment}

Surgical treatment was performed in order to correct the reflux points in the lower extremities studied. of the $63 \mathrm{LL}$ studied, 55 were submitted to radical magna saphenectomy (RMS) and to varicose vein exeresis (VE) with perforating ligation (PL) and 8 were submitted to RMS + PL + VE.

\section{Statistical analysis}

The three variables that represent the differences after surgical treatment, i.e., preoperative VFI - postoperative VFI, preoperative EF - postoperative EF, and preoperative RVF postoperative RVF, did not show normal distribution by the Kolmogorov-Smirnov test $(p<0.01)$. Thus, the data were analyzed by nonparametric tests, with the level of significance set at $\mathrm{p} \leq 0.05$.

The hemodynamic change was analyzed after exeresis of the varicose veins and was correlated with the clinical criterion of CEAP based on the nonparametric Kruskal-Wallis test and the post hoc Dunn test if necessary.

\section{Results}

The median, quartile and mean values of the difference obtained between the pre- and postoperative values of the variables VFI, EF and RVF and their correlation with the CEAP classification are presented in Tables 1, 2 and 3, respectively.

TABLE 1 - Mean, median and quartile (P25, P50 and P75\%) values of the pre- and postoperative hemodynamic difference of the venous filling index (VFI) of groups $\mathrm{C}_{2}+\mathrm{C}_{3}, \mathrm{C}_{4}$ and $\mathrm{C}_{5}+\mathrm{C}_{6}$

\begin{tabular}{ccccccc}
$\begin{array}{c}\text { VFI } \\
\text { Groups }\end{array}$ & N & $\begin{array}{c}\text { 1st } \\
\text { Quartile(P25) }\end{array}$ & $\begin{array}{c}\text { Median } \\
(\mathbf{P 5 0})\end{array}$ & $\begin{array}{c}\text { 3rd } \\
\text { Quartile(P75) }\end{array}$ & Mean & $\begin{array}{c}\text { Standard } \\
\text { deviation }\end{array}$ \\
\hline $\mathrm{C}_{2}+\mathrm{C}_{3}$ & 38 & 0.07 & 0.72 & 2.36 & 1.34 & 1.80 \\
$\mathrm{C}_{4}$ & 15 & 0.73 & 1.87 & 4.24 & 2.60 & 2.09 \\
$\mathrm{C}_{5}+\mathrm{C}_{6}$ & 10 & 1.21 & 2.75 & 6.33 & 3.29 & 3.13 \\
\hline
\end{tabular}

$\mathrm{W}=6.39$

$\mathrm{n}=$ number of limbs

$\mathrm{p}=0.04$

VFI values $=($ preoperative VFI - postoperative VFI $) \mathrm{ml} / \mathrm{s}$

It can be seen that the difference of VFI tended to increase in all groups, but the values of group $\mathrm{C}_{5}+\mathrm{C}_{6}$ were significantly higher than those of group $\mathrm{C}_{2}+\mathrm{C}_{3}$. There was no difference between group $\mathrm{C}_{2}+\mathrm{C}_{3}$ and group $\mathrm{C}_{4}$ or between $\mathrm{C}_{4}$ and $\mathrm{C}_{5}+\mathrm{C}_{6}$ (Table 1).

TABLE 2 - Mean, median and quartile (P25, P50 and P75\%) values of the pre- and postoperative hemodynamic difference of the ejection fraction (EF) of groups $\mathrm{C}_{2}+\mathrm{C}_{3}, \mathrm{C}_{4}$ and $\mathrm{C}_{5}+\mathrm{C}_{6}$

\begin{tabular}{ccccccc}
\hline $\begin{array}{c}\text { VFI } \\
\text { Groups }\end{array}$ & N & $\begin{array}{c}\text { 1st } \\
\text { Quartile(P25) }\end{array}$ & $\begin{array}{c}\text { Median } \\
(\mathbf{P 5 0})\end{array}$ & $\begin{array}{c}\text { 3rd } \\
\text { Quartile(P75) }\end{array}$ & Mean & $\begin{array}{c}\text { Standard } \\
\text { deviation }\end{array}$ \\
\hline $\mathrm{C}_{2}+\mathrm{C}_{3}$ & 38 & -24.83 & -4.25 & 2.98 & -9.84 & 22.05 \\
$\mathrm{C}_{4}$ & 15 & -38.60 & -18.30 & -7.90 & -22.91 & 17.35 \\
$\mathrm{C}_{5}+\mathrm{C}_{6}$ & 10 & -29.03 & -14.75 & 16.95 & -9.71 & 30.63 \\
\hline
\end{tabular}

$\mathrm{W}=4.14$

$\mathrm{n}=$ number of limbs

$\mathrm{p}=0.13$

$\mathrm{EF}$ values $=($ preoperative $\mathrm{EF}-$ postoperative $\mathrm{EF}) \%$ 
TABLE 3 - Mean, median and quartile (P25, P50 and P75\%) values of the pre- and postoperative hemodynamic difference of the residual volume fraction (RVF) of groups $\mathrm{C}_{2}+\mathrm{C}_{3}, \mathrm{C}_{4}$ and $\mathrm{C}_{5}+\mathrm{C}_{6}$

\begin{tabular}{ccccccc}
\hline $\begin{array}{c}\text { VFI } \\
\text { Groups }\end{array}$ & N & $\begin{array}{c}\text { 1st } \\
\text { Quartile(P25) }\end{array}$ & $\begin{array}{c}\text { Median } \\
(\text { P50) }\end{array}$ & $\begin{array}{c}\text { 3rd } \\
\text { Quartile(P75) }\end{array}$ & Mean & $\begin{array}{c}\text { Standard } \\
\text { deviation }\end{array}$ \\
\hline $\mathrm{C}_{2}+\mathrm{C}_{3}$ & 38 & -8.10 & 4.25 & 19.10 & 9.14 & 25.84 \\
$\mathrm{C}_{4}$ & 15 & -5.10 & 7.50 & 35.40 & 12.41 & 19.21 \\
$\mathrm{C}_{5}+\mathrm{C}_{6}$ & 10 & -12.56 & 8.65 & 32.60 & 5.32 & 32.44 \\
\hline $\mathrm{W}=0,32$ & \\
$\mathrm{p}=0,85$ \\
$\mathrm{n}=$ number of limbs; RVF values = (preoperative RVF- postoperative RVF) \%
\end{tabular}

There was no difference between groups regarding EF or RVF, i.e., the hemodynamic changes of EF and RVF were not correlated with clinical severity (Tables 2 and 3).

\section{Discussion}

Many studies have quantitated the venous reflux obtained by APG and have demonstrated that the parameters obtained can be correlated with the clinical stages and can also be used to monitor the results of venous surgery after different types of intervention ${ }^{2,3,5-14}$. The importance of superficial venous reflux in advanced stages of venous diseases has been studied by several investigators, who concluded that more than $50 \%$ of their patients with phlebopathic ulcers only had superficial venous insufficiency ${ }^{15}$.

The objective of the present study was to assess the hemodynamic changes occurring after venous surgery in patients with superficial venous insufficiency and with a competent deep venous system and to correlate these changes with the CEAP classification.

Pre and postoperative analysis of VFI and of its correlation with the CEAP classification revealed that, the greater the clinical severity, the greater the hemodynamic change after surgical treatment. The $\mathrm{C}_{5}+\mathrm{C}_{6}$ group had the greatest hemodynamic change, i.e., the VFI of this group had higher preoperative values and was significantly reduced after surgery.

Apparently, the two groups of patients with less severe disease $(\mathrm{C} 2+\mathrm{C} 3$ and $\mathrm{C} 4)$ benefited from surgical treatment in terms of VFI, but the greatest hemodynamic gain was obtained in the group of greater clinical severity $\left(\mathrm{C}_{5}+\mathrm{C}_{6}\right)$. It was also observed that EF and RVF did not contribute to a correlation of the hemodynamic change obtained after surgical treatment with the clinical CEAP classification.

Christopoulos et al..$^{16}$ studied the pre and postoperative hemodynamic alterations of 42 limbs surgically treated for varicose veins using APG. The preoperative VFI of these limbs was more than $2 \mathrm{ml} / \mathrm{s}$ and was reduced after surgical treatment in 24 limbs (57.1\%). EF increased and RVF decreased after surgery. They did not calculate a correlation with the CEAP classification because the classification had not yet been established in the literature.
Gillespie et $a l .{ }^{3}$ also assessed the venous hemodynamics after different types of surgery for varicose veins and concluded that APG is an efficient and noninvasive method for the quantitative assessment of the results of reconstructive venous surgery. They also concluded that the VFI is the best variable to be used to represent the degree of venous reflux. In the present study, we did not correlate the hemodynamic changes with the technique or type of surgery performed, but only with the CEAP classification.

Jiang et $a l .{ }^{5}$, after evaluating 253 limbs with recurrent varicose veins concluded that more severe physiological disorders are a priority in terms of surgical reintervention and that VFI is the parameter that best indicates venous reflux and clinical severity. Similar results regarding VFI were detected in a previous study by the authors ${ }^{17}$, i.e., the higher the VFI the more severe the clinical CEAP classification.

Nishibe et $a l .{ }^{7}$ and Miyazaki et al. ${ }^{9}$ used APG as a noninvasive method for the evaluation of changes in venous hemodynamics before and after different types of superficial venous surgeries. They concluded that there was no difference between types of superficial venous surgery regarding venous hemodynamics as long as the technique used normalized VFI, which is considered to be the best parameter representing venous reflux.

Park et al..$^{10}$ analyzed 1756 limbs of 1620 patients operated upon for primary varicose veins and, on the basis of the variables obtained by APG, concluded that there was a postoperative hemodynamic gain. Although this study involved a large number of patients, the authors did not correlate the hemodynamic gain with CEAP classification.

In the present study, although EF and RVF did not discriminate the postoperative hemodynamic change that occurred in the three patient groups, VFI was able to demonstrate that the group of highest severity according to the CEAP classification obtained the highest gain of venous hemodynamics.

Thus, superficial venous surgery is considered to be an appropriate form of treatment in the attempt to interrupt the physiopathological course of venous hypertension at any level of clinical severity. Although the two groups of patients with less severe disease $(\mathrm{C} 2+\mathrm{C} 3$ and $\mathrm{C} 4)$ apparently benefited from treatment, the group with highest disease severity (C5+C6) obtained the highest hemodynamic gain. 


\section{Conclusion}

Surgical treatment was beneficial for all three groups, but the greatest hemodynamic gain was observed in the group of highest clinical severity (group $\mathrm{C}_{5}+\mathrm{C}_{6}$ ).

\section{References}

1. Souza E, Suzuki RT, Veloso MVX, Ribeiro FRCM. Estudos dos fatores de risco nos pacientes portadores de varizes dos membros inferiores em serviço público de saúde. Rev Ang Cir Vasc. 2005;4:161-4.

2. Christopoulos D, Nicolaides AN, Szendro G. Venous reflux: Quantification and correlation with the clinical severity of chronic venous disease. Br J Surg. 1988;75:352-6.

3. Gillespie DL, Cordts PR, Hartono C, Woodson J, Obi-Tabot E, Lamorte WW, Menzoian JO. The role of air plethysmography in monitoring results of venous surgery. J Vasc Surg. 1992;16:674-8.

4. Sakuda H, Nakaema M, Matsubara S, Higa N, Kamada Y, Kuniyoshi Y, Koja K. Air plethysmographic assessment of external valvuloplasty in patients with valvular incompetence of the saphenous and deep veins. $\mathbf{J}$ Vasc Surg. 2002;36:922-7.

5. Jiang P, Vanrij AM, Christie RA, Hill GB, Thomson IA. Venous physiology in the different patterns of recurrent varicose veins and the relationship to clinical severity. Cardiovasc Surg. 2000;8:130-6.

6. Van Rij AM, Jiang P, Solomon C, Christie RA, Hill GB. Recurrence after varicose vein surgery: a prospective long-term clinical study with duplex ultrasound scanning and air plethysmography. J Vasc Surg. 2003;38:935-43.

7. Nishibe T, Nishibe M, Kudo F, Flores J, Miyazaki K, Yasuda K. Stripping operation with preservation of the calf saphenous veins for primary varicose veins: hemodynamic evaluation. Cardiovasc Surg. 2003;11:341-5.
8. Kim IH, Joli JH, Kim DI. Venous hemodynamic changes in the surgical treatment of primary varicose vein of the lower limbs. Yonsei Med J. 2004;45:577-83.

9. Miyazaki K, Nishibe T, Kudo F, Miyazaki YJ, Nishibe M, Ando M, Yasuda K. Hemodynamic changes in stripping operation or saphenofemoral ligation of the greater saphenous vein for primary varicose veins. Ann Vasc Surg. 2004;18:465-9.

10. Park UJ, Yun WS, Lee KB, Rho YN, Kim YW, Joh JH, Kim DI. Analysis of the postoperative hemodynamic changes in varicose vein surgery using air plethysmography. J Vasc Surg. 2010;51:634-8.

11. Christopoulos D, Nicolaides AN, Cook A, Irvine A, Galloway JM, Wilkinson A. Pathogenesis of venous ulceration in relation to the calf muscle pump function. Surgery. 1989;106:829-35.

12. Porter JM, Moneta GL. Reporting standards in venous disease: an update. International Consensus Committee on Chronic Venous Disease. J Vasc Surg. 1995;21:635-45.

13. Evangelista SSM, Fonseca FP. O valor da fotopletismografia no pré e pós-operatório das varizes tronculares primárias dos membros inferiores. Cir Vasc Angiol. 1996;4:59-62.

14. Owens LV, Farber MA, Yong ML, Carlin RE, Criado-Pallares E, Passman MA, Keagv BA, Marston WA. The value of air plethysmography in predicting clinical outcome after surgical treatment of chronic venous insufficiency. J Vasc Surg, 2000;32;961-8.

15. Ting AC, Cheng SW, Wu LL, Cheung GC. Changes in venous hemodynamics after superficial vein surgery for mixed superficial and deep venous insufficiency. World J Surg. 2001;25:122-5.

16. Christopoulos D, Nicolaides AN, Galloway JM, Wilkinson A. Objective noninvaise evaluation of venous surgical results. J Vasc Surg. 1988;8:683-7.

17. Dezotti NRA, Joviliano EE, Toma MK, Moriya T, Piccinato CE. Venous hemodynamic study by airplethysmography in the pre- and postoperative period of lower limb varicose veins J Vasc Bras. 2009;8:21-8.

\section{Correspondence:}

\section{Nei Rodrigues Alves Dezotti}

Faculdade de Medicina de Ribeirão Preto-USP

Departamento de Cirurgia e Anatomia

Divisão de Cirurgia Vascular e Endovascular

Av. Bandeirantes, 3900

Campus Universitário Monte Alegre

14048-900 Ribeirão Preto - SP Brasil

Tel.: (55 16) 3602-2593

neidezotti@yahoo.com.br

Conflict of interest: none

Financial source: Fundação de Apoio ao Ensino, Pesquisa e Assistência do Hospital das Clínicas da Faculdade de Medicina de Ribeirão Preto da Universidade de São Paulo (FAEPA-HC/FMRP-USP)

${ }^{1}$ Research performed at Division of Vascular and Endovascular Surgery, Department of Surgery and Anatomy, Faculty of Medicine of Ribeirao Preto, University of Sao Paulo (FMRP-USP), Brazil.

Presented at the XII National Congress on Experimental Surgery of the Brazilian Society for Development of Research in Surgery-SOBRADPEC, 2011 October 26-29 Ribeirao Preto-SP, Brazil. 